\title{
Seasonal Variation, Chemical Composition and Antioxidant activity of Brazilian Propolis Samples
}

\author{
Érica Weinstein Teixeira ${ }^{1}$, Dejair Message ${ }^{2}$, Giuseppina Negri ${ }^{3}$, Antonio Salatino $^{4}$ \\ and Paulo César Stringheta ${ }^{5}$
}

${ }^{1}$ Agência Paulista de Tecnologia dos Agronegócios - Secretaria de Agricultura e Abastecimento/SP, Caixa Postal - 07. 12.400-970, Pindamonhangaba, SP, ${ }^{2}$ Universidade Federal de Viçosa, Departamento de Biologia Animal, 36.571-000, Viçosa, MG, ${ }^{3}$ Universidade Federal de São Paulo, Departamento de Psicobiologia, Rua Botucatu, 862, Edifício Biomédicas, $1^{\circ}$ andar, CEP - 04023-062, São Paulo, SP, ${ }^{4}$ Universidade de São Paulo, Instituto de Biociências, Departamento de Botânica, C. Postal. 11461, 05.422-970, São Paulo, SP and

${ }^{5}$ Universidade Federal de Viçosa, Departamento de Tecnologia de Alimentos, 36.571 -000, Viçosa, MG, Brazil

Total phenolic contents, antioxidant activity and chemical composition of propolis samples from three localities of Minas Gerais state (southeast Brazil) were determined. Total phenolic contents were determined by the Folin-Ciocalteau method, antioxidant activity was evaluated by DPPH, using BHT as reference, and chemical composition was analyzed by GC/MS. Propolis from Itapecerica and Paula Cândido municipalities were found to have high phenolic contents and pronounced antioxidant activity. From these extracts, 40 substances were identified, among them were simple phenylpropanoids, prenylated phenylpropanoids, sesquiand diterpenoids. Quantitatively, the main constituent of both samples was allyl-3prenylcinnamic acid. A sample from Virginópolis municipality had no detectable phenolic substances and contained mainly triterpenoids, the main constituents being $\alpha$ - and $\beta$-amyrins. Methanolic extracts from Itapecerica and Paula Cândido exhibited pronounced scavenging activity towards DPPH, indistinguishable from BHT activity. However, extracts from Virginópolis sample exhibited no antioxidant activity. Total phenolic substances, GC/MS analyses and antioxidant activity of samples from Itapecerica collected monthly over a period of 1 year revealed considerable variation. No correlation was observed between antioxidant activity and either total phenolic contents or contents of artepillin $\mathrm{C}$ and other phenolic substances, as assayed by $\mathrm{CG} / \mathrm{MS}$ analysis.

Keywords: antioxidant activity-Apis mellifera-Baccharis dracunculifolia-DPPH - propolisseasonality

\section{Introduction}

Propolis is currently a popular alternative medicine in various parts of the world, including Japan and the European Union. It is a complex mixture of substances collected by honeybees from buds or exudates of plants

For reprints and all correspondence: Antonio Salatino, University of São Paulo, Institute of Biosciences, Department of Botany, C. Postal 11461, 05422-970, São Paulo, SP, Brazil. Tel: + 55-11-3091-7532;

Fax: +55-11-3091-7416; E-mail: asalatin@ib.usp.br (resin), beeswax and other substances, such as pollen and sugars. Plant source, physicochemical properties and antibacterial activity are important parameters for propolis quality evaluation (1).

Leaf-buds of Populus nigra (black poplar) are sources of propolis resin in temperate regions (2). Propolis resin from Europe and China contain predominantly flavonoids and secondarily phenolic acid esters (3). Iranian propolis has been shown to contain aromatic acids (benzoic and benzenepropanoic), esters of caffeic and 
phenylethyl-trans-4-coumaric acids, flavonoids (pinocembrin, chrysin), among other constituents (4). Instead, the resin source of the most prized Brazilian propolis, namely green or alecrim propolis, has been established as buds of Baccharis dracunculifolia ('alecrim'), an Asteraceae from southeast and western-central Brazil (5-7). Prenylated derivatives of $p$-coumaric acid predominate in alecrim propolis (5-11). Artepillin C (4-hydroxy-3,5-diprenyl cinnamic acid), drupanin (4-hydroxy-3-prenyl cinnamic acid) and (E)-3-prenyl-4-(dihydrocinnamoyloxy)-cinnamic acid were found in both $B$. dracunculifolia and propolis (12). Artepillin $\mathrm{C}$, drupanin, $p$-coumaric and caffeic acids are major constituents of a propolis sample from São Paulo state (southeast Brazil) (11). Recent paper (13) reported a new type of Brazilian propolis. It is red colored and contains compounds not found in alecrim propolis, including isoflavonoids and prenylated benzophenones.

Several biological activities, such as anticancer, antioxidant, anti-inflammatory, antiseptic, antimycotic, bacteriostatic, astringent, anti-ulcer, choleretic, spasmolytic and anaesthetic properties have been reported for propolis and its constituents (12-18). Alecrim propolis with high contents of artepillin $\mathrm{C}$ exhibited in vitro concentration-dependent toxicity on mouse NIH-3T3 fibroblasts, cells involved in cicatrization processes (13). Both in vitro and in vivo evidences were raised that alecrim propolis protects against retinal damage (19). Water extract of Brazilian alecrim propolis and some of its constituents, derived from caffeoylquinic acid, protect RGC-5 cells from oxidative stress-induced cell death (13).

Reactive oxygen species (ROS) are implicated in a wide range of human diseases, such as atherosclerosis and certain cancers. When an imbalance between ROS generation and antioxidants occurs, oxidative damage will spread over most cell targets (20) (DNA, lipids, proteins, etc). Hence, the study of antioxidant substances in foods and medicinal natural sources has gained increased interest. Such substances are currently recognized as effective aids for the treatment and prevention of human diseases. Among antioxidants, many stemming from plants have one or more phenolic hydroxyls. Phenolic compounds may exert antioxidant effects as free radical scavengers, as hydrogen donating sources or as singlet oxygen quenchers and metal ion chelators (21). Phenolic compounds are known to counteract oxidative stress in the human body by helping maintaining a balance between oxidant and antioxidant substances $(22,23)$.

Flavonoids and phenolic acids are major classes of phenolic compounds, whose structure-antioxidant activity relationships in aqueous or lipophilic systems have been extensively reported (24). In addition to antioxidant activity, many phenolic compounds have been shown to exert anticancer or anticarcinogenic/antimutagenic activity to a greater or lesser extent $(25,26)$.
Their physiological and pharmacological activities may be derived from their antioxidant properties, which are related to their molecular structure (27). Mechanisms of antioxidant action may include suppression of ROS formation, removal or inactivation of oxygen reactive species and up-regulation or protection of antioxidant defenses $(28,29)$.

Development and utilization of more effective antioxidants of natural origin are desired. Naturally occurring polyphenols are expected to help reducing the risk of various life-threatening diseases, including cancer and cardiovascular diseases, due to their antioxidant activity. Propolis possesses antioxidant activity, its constituents being able to scavenge free radicals (30). On the other hand, propolis chemical composition (and hence antioxidant activity) may vary widely according to locality, epoch of collection or simply comparing one hive with another (6). The purpose of the present study is to determine the chemical composition and antioxidant activity of three propolis samples, each from one locality of the state of Minas Gerais (southeast Brazil). It is expected that such analyses may help understanding relationships between composition and antioxidant activity. In addition, it is intended to evaluate the effects of seasonality on chemical composition and antioxidant activity of propolis samples from a same apiary collected over a period of 12 months.

\section{Methods}

\section{Material}

Propolis samples of Africanized Apis mellifera were collected monthly over a period of 1 year in three apiaries from the state of Minas Gerais (southeast Brazil), one of them in the municipality of Itapecerica (It) $\left(20^{\circ} 32^{\prime} \mathrm{S}, 45^{\circ} 13^{\prime} \mathrm{O}\right)$, another in Paula Cândido (PC) $\left(20^{\circ} 49^{\prime} \mathrm{S}, 42^{\circ} 54^{\prime} \mathrm{O}\right)$ and the third one in Virginópolis (Vi) $\left(18^{\circ} 50^{\prime} \mathrm{S}, 42^{\circ} 43^{\prime} \mathrm{O}\right)$. Samples were obtained from five Langstroth-type beehives at each apiary. Colonies were inside wooden boxes with apertures $3 \mathrm{~cm}$ wide along both lateral sides, where the produced propolis accumulated. During 12 months, propolis samples produced by five colonies in the three apiaries were monthly collected, powdered and maintained in freezer. Propolis samples were pooled, combining in identical quantities samples from the 12 months of each colony. Samples from Itapecerica apiary were collected at each month, but the identity each month of collection (It/Jan-It/Dec) was preserved, in order to evaluate seasonal influences.

\section{Extraction, Purification and Isolation of Compounds}

Samples $(5 \mathrm{~g})$ were treated with hexane for $3 \mathrm{~h}$ in Soxhlet and the extracts discarded. A second extraction in 
Soxhlet was carried out with methanol for $3 \mathrm{~h}$. Waxes still remaining in the extract were eliminated by three consecutive steps of cooling in freezer and filtrating. Wax-free extracts were concentrated under reduced pressure and the residue was dried to constant weight. The obtained residues (dry methanol extracts-DME) were weighed. Bauerenyl acetate, main component of propolis from another sample of Paula Cândido, was isolated according to procedures described in Teixeira et al. (31).

\section{Total Phenol Contents}

Total phenol contents in crude propolis and DMEs were determined by the Folin-Ciocalteau method according to Woisky and Salatino (32), with minor modifications. Propolis methanol extracts or DME solution (400 p.p.m.) was mixed with $6.0 \mathrm{ml}$ of the Folin-Ciocalteau and $6.0 \mathrm{ml}$ of $20 \% \mathrm{Na}_{2} \mathrm{CO}_{3}$, the absorbance being measured at $760 \mathrm{~nm}$ after $2 \mathrm{~h}$. A calibration curve with solutions of gallic acid was used as reference. Total phenol contents were expressed as percentages of total phenolic substances in crude propolis and DMEs and correspond to means of three replicates.

\section{GC/EIMS Analyses of Extracts}

Methylation of constituents of part of the wax-free DMEs was carried out with diazomethane. Diazomethane-treated and non-treated DMEs were dissolved in ethyl ether at the concentration of 1000 p.p.m. Ether solutions $(1 \mu \mathrm{l})$ were injected into a Shimadzu GCMS-QP5050A 17A ChemStation System Mass Spectrometer operating in the $\mathrm{EI}$ mode at $70 \mathrm{eV}$, equipped with auto injector AOC-5000 and mass selective detector. A DBS fused silica capillary column $(30 \mathrm{~m} \times 0.25 \mathrm{~mm}$ internal diameter, $0.25 \mu \mathrm{m}$ film thickness), $\mathrm{He}$ as carrier gas with flux $1.5 \mathrm{ml} \mathrm{min}^{-1}$ and splitless mode were used. Oven temperatures ranged from 100 to $310^{\circ} \mathrm{C}$ at $10^{\circ} \mathrm{C} \mathrm{min}{ }^{-1}$, followed by isothermal period of $30 \mathrm{~min}$. The range for mass detection was $\mathrm{m} / \mathrm{z} 40-500$. Injector and detector temperature was $300^{\circ} \mathrm{C}$. Compounds were identified by computer searches in reference libraries Wiley 229L PMW TOX2 and NIST MS, and comparison of fragmentation patterns with literature data. Solutions of some reference compounds were injected in order to assist in the identification.

\section{Free Radical Scavenging Activity}

DMEs were dissolved in ethanol and baurenyl acetate in chloroform. The reaction mixture contained $2 \mathrm{ml}$ ethanol, $0.1 \mathrm{mM}$ free radical 1,1-diphenyl-2-picrylhydrazyl $(\mathrm{DPPH})$ and DME. The methanolic extracts from Itapecerica (DME/It), Paula Candido (DME/PC) and
Virginópolis (DME/Vi) and 12 DMEs obtained from It (DME/ItJan - DME/ItDec) were dissolved in ethanol at 200 p.p.m. Triplicates were prepared at the proportion 1:6 (v/v), combining DME ethanolic solutions and DPPH solution, respectively. Methanolic extracts were evaluated at the final concentration of $20 \mu \mathrm{g} \mathrm{ml}^{-1}$. Controls were prepared combining ethanol and DPPH solutions also at the proportion 1:6 (v/v). After $30 \mathrm{~min}$ at room temperature, absorbances were measured at $517 \mathrm{~nm}$ (33). Intervals of $3 \mathrm{~min}$ were maintained between determination of absorbances. Ethanolic solutions of butylhydroxytoluene (BHT) at 200 p.p.m. were used as positive control. All experiments were carried out in triplicates. The antioxidant activity was expressed as percentage inhibition relative control value (BHT), after 30 min reaction, using the formula (33):

$$
\% \text { Inhibition }=\left[\frac{(\text { Abs DPPH }- \text { Abs test sample })}{\text { Abs DPPH }}\right] \times 100 \text {. }
$$

Comparison of antioxidant activities of DME/It/ Jan-DME/It/Dec was statistically evaluated using $F$-test with $5 \%$ of significance level. The statistical model included, as fixed effect, month of collection and residual as random effect. Free degree concerning this variation source was decomposed in contrasts and evaluated.

\section{Results}

\section{Chemical Analysis}

A total of 40 compounds, involving benzoic and cinnamic acid derivatives (phenylpropanoids), triterpenes, sesquiterpenes and diterpenes were found in DME/It, DME/PC and Virginópolis DME/Vi (Table 1), in addition to minor wax constituents (carboxylic acids and linear hydrocarbons). Non-prenylated (compounds 1-9) and prenylated cinnamic acid derivatives (compounds 10-17) were often detected.

Seasonality is an important factor determining propolis composition, since phenologic factors influence biosynthesis of plant secondary metabolites. Chemical composition of the methanolic extracts of propolis samples from Itapecerica, collected monthly along 1 year (DME/ItJan-DME/ItDec), are shown in Table 2.

\section{Total Phenol Contents}

Values of total phenol content as determined by the method of Folin-Ciocalteau of samples and extracts (DMEs) from It, PC, Vi and of DMEs of samples from Itapecerica collected monthly (DME/It/Jan-DME/It/ Dec) are shown in Table 3. 
Table 1. Relative percents of chemical constituents of dry methanolic extracts (DME) of propolis samples from Itapecerica (It), Paula Cândido (PC) and Virginópolis (Vi), municipalities from Minas Gerais state (southeast Brazil)

\begin{tabular}{|c|c|c|c|}
\hline Constituents & $\mathrm{DME} / \mathrm{It}$ & $\mathrm{DME} / \mathrm{PC}$ & $\mathrm{DME} / \mathrm{Vi}$ \\
\hline \multicolumn{4}{|l|}{ Simple phenylpropanoids } \\
\hline Dihydrocinnamic acid methyl ester (1) & 3.8 & 7.7 & - \\
\hline p-Hydroxydihydrocinnamic acid (3) & 0.5 & 0.4 & - \\
\hline$p$-Hydroxycinnamic acid ( $p$-coumaric acid) (4) & 1.0 & 2.0 & - \\
\hline p-Methoxycinnamic acid (5) & 1.5 & 2.0 & - \\
\hline trans-3-Methoxy-4-hydroxy-cinnamic acid (7) & 1.0 & 0.1 & - \\
\hline trans-3,4-Dimethoxycinnamic acid $(\mathbf{8})$ & 2.3 & 0.7 & - \\
\hline Dihydrocinnamic acid ethyl ester (9) & 2.5 & 3.2 & - \\
\hline \multicolumn{4}{|l|}{ Prenylated phenylpropanoids } \\
\hline 2,2-Dimethylchromene-6-propenoic acid (14) & 1.0 & 2.0 & - \\
\hline 2,2-Dimethyl-8-prenylchromene-6-propenoic acid (15) & 2.0 & 1.0 & - \\
\hline 8-(Methyl-butanechromane)-6-propenoic acid (16) & 0.1 & 0.1 & - \\
\hline 3-Hydroxy-2,2-dimethyl-8-prenylchromane-6-propenoic acid (17) & 3.7 & 2.5 & - \\
\hline \multicolumn{4}{|l|}{ Sesqui and diterpenoids } \\
\hline (-) Caryophyllene oxide (18) & - & - & 0.4 \\
\hline Farnesol (19) & 1.0 & - & - \\
\hline Farnesyl acetate $(\mathbf{2 0})$ & - & - & 0.8 \\
\hline Spathulenol (21) & 1.2 & 1.5 & 0.3 \\
\hline Bauer-7-en-3ß-yl acetate (27) & - & - & 6.5 \\
\hline$\alpha$-Amyrin (28) & - & - & 4.1 \\
\hline$\alpha$-Amyrin acetate (29) & - & - & 23.5 \\
\hline$\beta$-Amyrin acetate $(\mathbf{3 0})$ & - & - & 20.5 \\
\hline Lupeyl acetate (31) & - & - & 7.2 \\
\hline Olean-18-en-3ß-yl acetate (32) & - & - & 4.2 \\
\hline Taraxer-14-en-3 $\beta$-yl acetate $\mathbf{( 3 3 )}$ & - & - & 6.7 \\
\hline 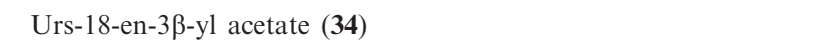 & - & - & 2.4 \\
\hline Friedooleanan-7,12-dien-3 $\beta$-yl acetate (35) & - & - & 1.4 \\
\hline \multicolumn{4}{|l|}{ Constituents from other classes } \\
\hline p-Vinylphenol (36) & 3.0 & 4.5 & - \\
\hline$p$-Vinyl-o-prenylphenol (37) & 8.4 & 9.8 & \\
\hline Quinic acid (38) & 0.8 & 0.6 & - \\
\hline 2-Hydroxy-7,12-dimethyl-benzanthracene (39) & 3.5 & 3.5 & - \\
\hline Isomaturnin $(\mathbf{4 0})$ & 2.0 & 2.0 & - \\
\hline
\end{tabular}


Table 2. Percents of constituents (Comp.) of methanolic extracts of samples from Itapecerica (Minas Gerais state, southeast Brazil) collected monthly over a period of 1 year

\begin{tabular}{|c|c|c|c|c|c|c|c|c|c|c|c|c|}
\hline Comp. $^{\mathrm{a}}$ & Jan & Feb & Mar & Apr & May & Jun & Jul & Aug & Sep & Oct & Nov & Dec \\
\hline 1 & 3.8 & 2.0 & 3.5 & 3.9 & 14.0 & 2.0 & 7.5 & 3.7 & 4.3 & 4.8 & 3.0 & 2.6 \\
\hline 2 & 3.0 & 2.5 & 2.5 & 1.5 & 2.0 & 2.0 & 2.5 & 2.5 & 2.0 & 1.0 & 2.5 & 2.0 \\
\hline 4 & 2.0 & 2.0 & 2.0 & - & 2.0 & 1.5 & 2.0 & 1.5 & 3.8 & 1.0 & 1.5 & 0.5 \\
\hline 5 & 2.0 & 0.4 & 3.5 & 5.5 & 1.0 & 3.7 & 3.0 & 5.0 & 1.5 & 1.5 & 1.5 & 1.0 \\
\hline 6 & 0.4 & 1.0 & 0.4 & - & - & 1.0 & 0.3 & 1.9 & 0.4 & - & - & - \\
\hline 8 & 1.5 & 0.2 & 4.5 & 3.2 & - & 1.0 & 1.0 & 3.5 & 0.8 & 0.8 & - & - \\
\hline 9 & 2.5 & - & 0.5 & - & - & 4.0 & 3.2 & - & - & 4.3 & - & 2.3 \\
\hline 10 & 15.0 & 25.0 & 19.6 & 24.0 & 23.0 & 25.0 & 22.5 & 27.5 & 22.7 & 32.7 & 24.0 & 23.1 \\
\hline 11 & 7.0 & 5.5 & 6.3 & - & 1.3 & 4.9 & 5.6 & 3.2 & 5.2 & 5.2 & 4.2 & 5.9 \\
\hline 12 & 7.0 & 9.8 & 7.0 & 3.2 & 2.8 & 5.5 & 5.6 & 4.3 & 8.6 & 10.2 & 5.4 & 12.5 \\
\hline 16 & 1.5 & 1.0 & 1.5 & 1.0 & 1.0 & 1.0 & 1.5 & 1.5 & 3.0 & 1.0 & 1.5 & 1.0 \\
\hline 17 & 1.5 & 1.5 & 3.0 & 2.5 & 3.0 & 4.5 & 3.0 & 2.0 & 2.0 & 2.0 & 2.0 & 1.0 \\
\hline 19 & 1.0 & 1.0 & 2.0 & 1.5 & 1.0 & - & - & 1.0 & - & 1.0 & 1.0 & 1.0 \\
\hline 20 & 2.5 & - & - & - & - & - & - & - & - & - & - & - \\
\hline 21 & 1.0 & 1.0 & - & - & - & 1.0 & - & 1.0 & - & 0.5 & - & 0.5 \\
\hline 22 & - & - & - & - & 1.5 & 1.4 & 1.0 & - & - & 2.5 & - & 1.0 \\
\hline 23 & 1.5 & 2.5 & 1.5 & 1.0 & 1.5 & 1.0 & 2.0 & 1.0 & 1.6 & 1.0 & 1.5 & 1.0 \\
\hline 24 & 1.5 & 7.5 & 1.0 & - & 1.5 & 2.5 & 1.0 & 4.0 & 2.0 & 1.5 & 1.5 & 1.5 \\
\hline 25 & 1.0 & 1.5 & 3.0 & 3.0 & 1.5 & 1.5 & 1.5 & 2.0 & - & 1.0 & 3.5 & 1.5 \\
\hline
\end{tabular}

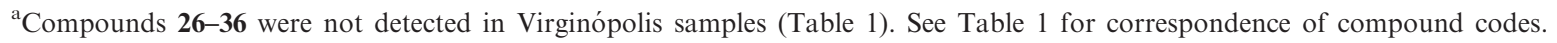

Table 3. Percents (means $\pm \mathrm{SE}$ ) of total phenolic substances in propolis samples from Minas Gerais (southeast Brazil)

\begin{tabular}{|c|c|c|c|c|c|}
\hline \multirow[b]{2}{*}{ Sample origin } & \multicolumn{2}{|c|}{ Total phenols } & \multicolumn{3}{|l|}{ Total phenols } \\
\hline & Sample & Extract $^{\mathrm{a}}$ & Sample origin & Sample $^{\mathrm{b}}$ & Extract $^{\mathrm{a}}$ \\
\hline Itapecerica & 11.8 & $20.5 \pm 0.0$ & DME/It/May & 16.2 & $26.4 \pm 0.2 \mathrm{~d}$ \\
\hline \multirow[t]{2}{*}{ Virginópolis } & 0.3 & $1.5 \pm 0.0$ & $\mathrm{DME} / \mathrm{It} / \mathrm{Jul}$ & 10.2 & $18.6 \pm 0.2 \mathrm{f}$ \\
\hline & & & DME/It/Aug & 14.4 & $21.9 \pm 0.2 \mathrm{e}$ \\
\hline DME/It/Jan & 8.9 & $15.5 \pm 0.2 \mathrm{a}$ & $\mathrm{DME} / \mathrm{It} / \mathrm{Sep}$ & 12.9 & $23.0 \pm 0.2 b$ \\
\hline DME/It/Mar & 12.6 & $20.9 \pm 0.2 \mathrm{c}$ & $\mathrm{DME} / \mathrm{It} / \mathrm{Nov}$ & 13.7 & $22.0 \pm 0.2 \mathrm{e}$ \\
\hline $\mathrm{DME} / \mathrm{It} / \mathrm{Apr}$ & 12.3 & $22.8 \pm 0.2 b$ & $\mathrm{DME} / \mathrm{It} / \mathrm{Dec}$ & 13.5 & $22.8 \pm 0.2 b$ \\
\hline
\end{tabular}

${ }^{\mathrm{a}}$ Same letters denote results significantly not different $(F$-test, $5 \%)$; ${ }^{\mathrm{b}} \mathrm{DME} / \mathrm{It} / \mathrm{Jan}-\mathrm{DME} / \mathrm{It} / \mathrm{Dec}$ : extracts obtained from samples collected monthly over a period of 1 year. 
Table 4. Antioxidant activity (percents, means \pm SE) of dry methanolic extracts (DME) towards the free radical DPPH

\begin{tabular}{|c|c|c|c|}
\hline Sample origin & Activity $^{\mathrm{a}}$ & Sample origin ${ }^{b}$ & Activity $^{\mathrm{a}}$ \\
\hline Itapecerica & 47.7 & DME/It/May & $61.1 \pm 2.4 \mathrm{~b}, \mathrm{c}$ \\
\hline Paula Cândido & 50.8 & DME/It/Jun & $54.6 \pm 2.4 \mathrm{~d}, \mathrm{e}, \mathrm{f}$ \\
\hline Virginópolis & 0.8 & DME/It/Jul & $54.4 \pm 2.4 \mathrm{e}, \mathrm{f}$ \\
\hline $\begin{array}{l}\text { Bauer-7-en-3 } \beta \text {-yl acetate } \\
\text { (a triterpenoid) }\end{array}$ & 0.0 & $\mathrm{DME} / \mathrm{It} / \mathrm{Aug}$ & $54.2 \pm 2.3 \mathrm{e}, \mathrm{f}$ \\
\hline $\mathrm{DME} / \mathrm{It} / \mathrm{Jan}$ & $50.0 \pm 2.4 \mathrm{~g}$ & $\mathrm{DME} / \mathrm{It} / \mathrm{Sep}$ & $58.3 \pm 2.3 \mathrm{c}, \mathrm{d}$ \\
\hline $\mathrm{DME} / \mathrm{It} / \mathrm{Feb}$ & $55.6 \pm 2.0 \mathrm{~d}, \mathrm{e}$ & $\mathrm{DME} / \mathrm{It} / \mathrm{Oct}$ & $58.3 \pm 2.1 \mathrm{c}, \mathrm{d}$ \\
\hline DME/It/Mar & $66.8 \pm 2.7 \mathrm{a}$ & $\mathrm{DME} / \mathrm{It} / \mathrm{Nov}$ & $63.4 \pm 2.1 \mathrm{a}, \mathrm{b}$ \\
\hline $\mathrm{DME} / \mathrm{It} / \mathrm{Apr}$ & $48.4 \pm 2.1 \mathrm{~g}$ & $\mathrm{DME} / \mathrm{It} / \mathrm{Dec}$ & $50.7 \pm 2.6 f, g$ \\
\hline
\end{tabular}

${ }^{a}$ Same letters denote results significantly not different ( $F$-test, $\left.5 \%\right)$; ${ }^{\mathrm{b}} \mathrm{DME} / \mathrm{It} / \mathrm{Jan}$ - DME/It/Dec: extracts obtained from samples collected monthly over a period of 1 year.

\section{Free Radical Scavenging Activity}

DPPH scavenging activities of DME are presented in Table 4. A consequence of the monthly compositional instability was a variation of antioxidant activity along the year, which ranged from $48.4 \%$ to $66.6 \%$. Results showed significant differences $(P<0.05)$, if the degrees of freedom for the fixed effect (months of the year) were decomposed in contrasts (Table 4). BHT (butylated hydroxytoluene) is a common antioxidant in the food chemistry and was used in this investigation as positive control. The scavenging activity of BTH was $64.6 \pm 2.3 \%$.

\section{Discussion}

\section{Chemical Composition}

Phenolics of DME/It and DME/PC were mainly simple and prenylated cinnamic acid derivatives. Artepillin C (4-hydroxy-3,5-diprenylcinnamic acid) (12), usually a major compound in alecrim propolis and so far detected only in Brazilian propolis, was found in the proportion of $8.7 \%$ in DME/It and of $14.9 \%$ in $\mathrm{DME} / \mathrm{PC}$, being second to allyl-3-prenylcinnamate (10) in both DME/It $(29.5 \%)$ and DME/PC (23.1\%) (Table 1). This compound was reported in alecrim propolis by Negri et al. (8). Other quantitatively important phenolic constituents found in $\mathrm{DME} / \mathrm{It}$ and $\mathrm{DME} / \mathrm{PC}$ were dihydrocinnamic acid methyl ester (1), 4-dihydrocinnamoiloxy-3-prenylcinnamic acid (13), $p$-vinylphenol (36) and $p$-vinyl-oprenylphenol (37) (Table 1). Although similar chemically, $\mathrm{DME} / \mathrm{It}$ and DME/PC have some salient differences, comparing the relative amounts of some of the mentioned constituents in one and another sample, such as $\mathbf{1}$ (higher in DME/PC), 10 (higher in DME/It) and $\mathbf{1 2}$ (higher in $\mathrm{DME} / \mathrm{PC})$. Other differences correspond to the presence of a compound in one extract and its apparent absence in another; such are the cases of farnesol (19) $(1.0 \%)$ and viridiflorol (22) (2.9\%) detected in DME/It and apparently absent in DME/PC (Table 1).

GC/MS chromatogram of DME/Vi showed a pattern deprived of phenolics. DME/Vi contained mainly triterpenoids 25-35, major constituents being $\alpha$ - and $\beta$-amyrin acetates, followed by squalene (25, an acyclic triterpenoid), bauer-7-en-3 $\beta$-yl-acetate (27), lupeyl acetate (31) and taraxer-14-en-3 $\beta$-yl acetate (33) (Table 1). Triterpenoid 27 was reported as the main constituent of another unusual propolis sample (29). Interestingly, Vi sample was also collected in southeast Minas Gerais, a region with predominance of 'green propolis', which is rich in prenylated phenolic compounds. Thus the plant origin of It and PC samples is probably B. dracunculifolia. However, the source of Vi sample is probably distinct from that of the two other samples.

\section{Chemical Composition-Seasonal Variation}

It seems that propolis samples with composition and physical properties deviating from the usual green pattern are relatively common in southeast Brazil. Seemingly, in samples of alecrim propolis there is a gradient with inversely proportional amounts of triterpenoids and phenolics, most samples characterized by high amounts of phenolics and low contents of triterpenoids. The characteristic alecrim pattern is hard, friable and dark green, with high amounts of phenolic compounds and low amounts of triterpenoids, or none at all. Increasing the amounts of triterpenoids and consequently decreasing those of phenolic compounds, samples progressively turn soft, dark, pitchy, greasy and sticky, or cream and powdery. Patterns such as the one described in this paper and that reported by Teixeira et al. (31) are uncommon and represent extremes, characterized by high amounts of triterpenoids and virtual absence of phenolics.

Most compounds of DME/It were detected throughout the year (Table 2). However, farnesyl acetate (20) was detected only in January. Other compounds (4-9, 11, 15, 19-22, 24, 25, 36 and 38) were detected in some months and not in others. For example, compound $\mathbf{1 1}$ appeared at the concentration of $6.3 \%$ in March, but was undetected in the following month. Contents of all compounds varied along the year (Table 2). Another study about seasonal chemical composition of Brazilian propolis (34) detected a pattern, according to which diterpenes started appearing in summer and reached a maximum in autumn, being absent along other seasons. No similar regular pattern of chemical variation was observed in the present study.

\section{Resin Plant Sources}

Propolis from Paula Cândido and Itapecerica no doubt derive from alecrim plants. On the other hand, a distinct 
resin source has to be assigned to Virginópolis sample. Indeed, microscopic observations using methodology published elsewhere (6) detected fragments of B. dracunculifolia as predominating plant residues in propolis from Itapecerica and Paula Cândido; on the other hand, in propolis from Virginópolis fragments of $B$. dracunculifolia were rare. Fragments of $B$. calvescens and Vernonia polyanthes were also detected, but main resin source of this propolis sample seem to be plant secretions of local species (Teixeira, Message and collaborators, unpublished data).

\section{Total Phenolic Percents}

$\mathrm{DME} / \mathrm{Vi}$ has a very low phenolic content $(1.5 \%)$, comparing with DME/It and DME/PC (20.5 and $21.9 \%$, respectively). DME/It and DME/PC did not contain triterpenoids (Table 1). Coherent with the analysis of total phenolic substances (Table 3), DME/It and DME/ PC exhibited a high diversity of phenolic compounds, while DME/Vi contains mainly triterpenoids (Table 1 ). DME/It/Jan corresponds to the lowest $(15.5 \%)$ and DME/It/May to the highest content $(26.4 \%)$. Such variation of total phenolic contents reflects variation of chemical compositions of the propolis extracts (Table 2).

\section{Antioxidant Activity}

DPPH scavenging capacity has been widely used for evaluating antioxidant capacity of natural extracts (35). Radical scavenging activity of phenolic compounds is assigned to the hydrogen-donating ability of compounds (36). Antioxidants intercept the free radical chain oxidation by donating hydrogen from the phenolic hydroxyl groups, thereby forming stable end products, which does not initiate or propagate further oxidation $(36,37)$. Nitrogen based radicals such as DPPH react with phenols by two mechanisms: (i) direct abstraction of phenol $\mathrm{H}$-atom and (ii) electron transfer from $\mathrm{ArOH}$ or its phenoxide anion $\left(\mathrm{ArO}^{-}\right)$to DPPH. The contribution of one pathway or another depends on the nature of the solvent and/or the redox potentials of the species involved (38). Radical scavenging activity of phenolic acids and their esters generally depends on numbers of phenolic hydroxyl groups (39-41). The hydro/lipophilicity of a sample does not affect its DPPH scavenging activity (42). Being rapid, simple and independent of sample polarity, the DPPH method is very convenient for the rapid screening of many samples for radical scavenging activity (43). Bioavailability is affected by conjugation of the compounds, and activity is mostly contributed by free forms $(36,44)$.

Artepillin C, a phenol from Brazilian propolis, with a single ring and two prenyl groups, is a bio-available antioxidant, whose activity has been evaluated by several works $(36,37)$. Simple phenols seem to be refractory to conjugation and the two prenyl groups of artepillin $\mathrm{C}$ may be an obstacle for conjugation to the hydroxyl (36). This phenolic compound undergoes intestinal absorption and prevents oxidative damage in hepatocytes and is assumed to prevent degenerative diseases by acting on cellular DNA (36). Other compounds with phenolic hydroxyls observed in the present work are 11, 37 and 39 (Table 1). The phenylpropanoid with highest relative content in DME/It and DME/PC, compound 10, is devoid of hydroxyl groups and hence probably has low antioxidant activity.

High antioxidant activities were obtained with DME/ PC (50.8\%) and DME/It (47.7\%), a result coherent with the relatively high contents of phenolic compounds in boths DMEs. On the other hand, antioxidant activity in DME/Vi was hardly noticed $(0.8 \%$, Table 4$)$. This sample contains mainly triterpenoids and virtually no phenolic substances (Table 1). One of the triterpenoids detected is bauer-7-en-3 $\beta$-yl acetate (27, Table 1), which was obtained as a major constituent of a propolis sample also from Paula Cândido, Minas Gerais (31). This compound was shown to have no antioxidant activity (Table 4). A puzzling circumstance of propolis production, which is a serious barrier towards standardization of the product, is the occurrence of samples with such distinct chemical compositions in the same geographic region.

\section{Antioxidant Activity-Seasonal Variation}

DME/It and DME/PC showed $74.6 \%$ and $79.5 \%$ of the BHT activity, respectively. Months with higher DPPH free radical scavenging activity of DME/It were March and November, followed by May, September and October (Table 4). Activities of DME/It/Mar (66.8\%) and DME/It/Nov $(63.4 \%)$ were statistically not distinct from BHT activity. Less effective extracts were DME/It/ Apr, DME/It/Jan and DME/It/Dec. DME/It/May, in spite of bearing the highest total phenolic content value (26.4\%, Table 3), exhibited only the third highest DPPH scavenging activity $(61.1 \%$, Table 4$)$. The extracts that exhibited lower total phenolic contents were DME/It/Jan, DME/It/Jul and DME/Itj/Mar, with 15.5, 18.6 and $20.9 \%$, respectively (Table 3 ). While $\mathrm{DME} / \mathrm{It} / \mathrm{Jan}$ is among the extracts with weakest DPPH free radical scavenging activity (50.0\%), DME/It/Mar showed an antioxidant activity similar to BHT $(66.8 \%$, Table 4$)$.

\section{Factors Influencing Antioxidant Activity}

Comparing antioxidant activities with total phenolic contents, no clear correlation is apparent regarding these $\mathrm{DME} / \mathrm{It}$ parameters along the year. Antioxidant activities are dependent on structures of phenolic compounds. For example, assuming identical patterns of hydroxyl and methoxyl substitution, hydroxycinnamic acids are 
more effective than hydroxybenzoic acids (39,45). In addition, antioxidant activity of phenolic acid derivatives depends on characteristics of both propane side chain and phenolic hydroxyls (22). Thus, structural aspects are important in determining antioxidant activity, which makes the subject of antioxidant activity too complex to be explained just in terms of quantity of phenolic compounds.

There is still the possibility of correlations between antioxidant activity and contents of total hydroxylated substances. Regarding propolis composition, likely compounds with high antioxidant activity are those bearing phenolic hydroxyls, such as compounds $3, \mathbf{4}, \mathbf{6}, \mathbf{7}, \mathbf{1 1}, \mathbf{1 2}$, 36, 37 and 39 (Table 1). Months with higher antioxidant activities were March, May and November (periods with scavenging activity above $60 \%$, Table 4). However, months when the sum of the percents of those compounds reached higher values (above $31.0 \%$ ) were July $(39.3 \%)$, September $(39.1 \%)$, February $(38.3 \%)$, January $(33.7 \%)$, October $(32.5 \%)$ and December (32.2\%) (Table 2). So, no correlation is apparent between DPPH scavenging activity and concentration of assumed active antioxidant compounds, revealing again how difficult it is to assign antioxidant efficacy to a limited set of components in complex mixtures, such as the case of propolis extracts. Constituents other than the most obvious powerful antioxidants probably play important roles in the final and observable effect. Even synergisms cannot be overruled in such cases.

\section{Antioxidant Activity—Concluding Remarks}

Lipid peroxidation is a probable cause of many health problems. Brazilian propolis has been shown to exert neuroprotective effect by inhibiting neurotoxicity in neuronally differentiated $\mathrm{PC} 12$ cell cultures. A protection against oxidative stress by propolis has been suggested to be responsible, at least partly, for the observed neuroprotection (46). Synthetic antioxidants, such as butylated hydroxyanisole (BHA), butylated hydroxytoluene (BHT) and tert-butylhydroquinone (TBHQ), are widely used in the food industry, although BHA and BHT have been under suspicion of being responsible for liver damage and carcinogenesis in laboratory animals $(47,48)$. Suppression of lipid antioxidant reactions in food is a major cause of quality deterioration and off-flavor development. Antioxidants may be used to preserve food quality from oxidative deterioration of lipids. Therefore, antioxidants may be used to avoid lipid deterioration and play an important role in food industry.

In addition to being a source of natural products capable of promoting radical scavenging beneficial effects in human and animal healthcare, propolis might end up as a source of model compounds for antioxidants useful in the food industry.

\section{Acknowledgments}

Funds provided by $\mathrm{CNPq}$ (Conselho Nacional do Desenvolvimento Cientifíco e Tecnológico, Brazil) are acknowledged.

\section{References}

1. Volpi N, Bergonzini G. Analysis of flavonoids from propolis by on-line HPLC-electrospray mass spectrometry. J Pharm Biomed Anal 2006;42:354-61.

2. Bankova V, Dyulgerov A, Popov S, Evstatieva L, Kuleva L, Pureb O, et al. Propolis produced in Bulgaria and Mongolia phenolic compounds and plant-origin. Apidologie 1992;23:79-85.

3. Bankova V, Castro SL, Marcucci MC. Propolis: recent advances in chemistry and plant origin. Apidologie 2003;31:3-15.

4. Mohammadzadeh S, Shariatpanahi M, Hamedi M, Ahmadkhaniha R, Samadi N, Ostad SN. Chemical composition, oral toxicity and antimicrobial activity of Iranian propolis. Food Chem 2007;103:1097-103.

5. Midorikawa K, Banskota AH, Tezuka Y, Nagaoka T, Matsushige $\mathrm{K}$, Message $\mathrm{D}$, et al. Liquid chromatographymass spectrometry analysis of propolis. Phytochem Anal 2001;12:366-73.

6. Teixeira EW, Negri G, Meira RMSA, Message D, Salatino A. Plant origin of green propolis: bee behavior, plant anatomy and chemistry. Evid Based Complement Alternat Med 2005;2:85-92.

7. Salatino A, Teixeira EW, Negri G, Message D. Origin and chemical variation of Brazilian propolis. Evid Based Complement Alternat Med 2005;2:33-8.

8. Banskota AH, Tezuka Y, Adnyana IK, Midorikawa K, Matsushige K, Kadota S. Hepatoprotective and anti-Helicobacter pylori activities of constituents from Brazilian propolis. Phytomedicine 2001;8:16-23.

9. Negri G, Salatino MLF, Salatino A. "Green propolis": unreported constituents and a novel compound from chloroform extracts. J Apic Res 2003;42:39-41.

10. Bankova V. Recent trends and important developments in propolis research. Evid Based Complement Alternat Med $2005 ; 2: 29-32$.

11. Kumazawa S, Yoneda M, Shibata I, Kanaeda J, Hamasaka T, Nakayama T. Direct evidence for the plant origin of Brazilian propolis by the observation of honeybee behavior and phytochemical analysis. Chem Pharm Bull 2003;51:740-2.

12. Trusheva B, Popova M, Bankova V, Simova S, Marcucci MC, Miorin PL, et al. Bioactive constituents of Brazilian propolis. Evid Based Complement Alternat Med 2006;3:249-54.

13. Funari CS, Ferro VDO, Mathor MB. Analysis of propolis from Baccharis dracunculifolia DC. (Compositae) and its effects on mouse fibroblasts. J Ethnopharmacol 2007;111:206-12.

14. de Barros MP, Sousa JPB, Bastos JK, de Andrade SF. Effect of Brazilian green propolis on experimental gastric ulcers in rats. J Ethnopharmacol 2007;110:567-71.

15. Nakajima Y, Shimazawa M, Mishima S, Hara H. Water extract of propolis and its main constituents, caffeoylquinic acid derivatives, exert neuroprotective effects via antioxidant actions. Life Sci 2007;80:370-7.

16. Usia T, Banskota AH, Tezuka Y, Midorikawa K, Matsushige K, Kadota S. Constituents of chinese propolis and their antiproliferative activities. J Nat Prod 2002;65:673-6.

17. Speciale A, Costanzo R, Puglisi S, Musumeci R, Catania MR, Caccamo $\mathrm{F}$, et al. Antibacterial activity of propolis and its active principles alone and in combination with macrolides, beta-lactams and fluoroquinolones against microorganisms responsible for respiratory infections. J Chemother 2006;18:164-71.

18. Paulino N, Teixeira C, Martins R, Scremin A, Dirsch VM, Vollmar AM, et al. Evaluation of the analgesic and antiinflammatory effects of a Brazilian green propolis. Planta Med 2006;72:899-906.

19. Inokuchi Y, Shimazawa M, Nakajima Y, Suernori S, Mishima S, Hara H. Brazilian green propolis protects against retinal damage in vitro and in vivo. Evid Based Complement Alternat Med 2006;3:71-7. 
20. Ortial S, Durand G, Poeggeler B, Polidori A, Papolla MA, Böker J, et al. Fluorinated amphiphilic amino acid derivatives as antioxidant carriers: a new class of protective agents. $\mathrm{J}$ Med Chem 2006;49:2812-20.

21. Okawa M, Kinjo J, Nohara J, Ono M. DPPH (1,1-diphenyl-2picryl-hidrazyl) radical scavenging activity of flavonoids obtained from some medicinal plants. Biol Pharm Bull 2001;24:1202-5.

22. Materska M, Perucka I. Antioxidant activity of the main phenolic compounds isolated from hot pepper fruit (Capsicum annuит L.). J Agric Food Chem 2005;53:1750-6.

23. Siddhuraju P. The antioxidant activity and free radical-scavenging capacity of phenolics of raw and dry heated moth bean (Vigna aconitifolia) (Jacq.) Marcchal seed extracts. Food Chem 2006;99:149-57.

24. Nenadis N, Wang LF, Tsimidou M, Zhang HY. Estimation of scavenging activity of phenolic compounds using the ABTS ${ }^{+}$ assay. J Agric Food Chem 2004;52:4669-74.

25. Tapiero H, Tew KD, Ba N, Mathé G. Polyphenols: do they play a role in the prevention of human pathologies? Biomed Pharmacother 2002;56:200-7.

26. Awale S, Shrestha SP, Tezuka Y, Ueda J, Matsushige K, Kadota S. Neoflavonoids and related constituents from Nepalese propolis and their nitric oxide production inhibitory activity. J Nat Prod 2005;68:858-64.

27. Heim KE, Tagliaferro AR, Bobilya DJ. Flavonoids antioxidants: chemistry, metabolism and structure-activity relationships. $J$ Nutr Biochem 2002;13:572-84

28. Van Acker SABE, Van den Berg DJ, Tromp MNJL, Griffioen DH, Van Bennekom WP, Van der Vijgh WJF, et al. Structural aspects of antioxidant activity of flavonoids. Free Radic Biol Med 1996:20:331-432.

29. Montoro P, Braca A, Pizza C, De Tommasi N. Structureantioxidant activity relationships of flavonoids isolated from different plant species. Food Chem 2005;92:349-55.

30. Kumazawa S, Hamasaka T, Nakayama T. Antioxidant activity of propolis of various geographic origins. Food Chem 2004;84:329-39.

31. Teixeira EW, Negri G, Meira RMAS, Message D, Salatino AC. Bauer-7-en-3 $\beta$-yl acetate: a major constituent of unusual samples of Brazilian propolis. Quim Nova 2006;29:245-46.

32. Woisky RG, Salatino A. Analysis of propolis: some parameter and procedures for chemical quality control. J Apic Res 1998:37:99-105.

33. Germano MP, Pasquale R, D'Angelo V, Catania S, Silvari V, Costa C. Evaluation of extracts and isolated fraction from Capparis spinosa L. buds as an antioxidant source. J Agric Food Chem 2002;50:1168-71.

34. Bankova V, Boudourova-Krasteva G, Popov S, Sforcin JM, Funari SRC. Seasonal variations of the chemical composition of Brazilian propolis. Apidologie 1998;29:361-7.

35. Surveswaran S, Cai YZ, Corke H, Sun M. Systematic evaluation of natural phenolic antioxidants from 133 Indian medicinal plants. Food Chem 2007;102:938-53.
36. Jayaprakasha GK, Ohnishi-Kameyama M, Ono H, Yoshida M, Jaganmohan Rao L. Phenolic constituents in the fruits of Cinnamomum zeylanicum and their antioxidant activity. J Agric Food Chem 2006;54:1672-9.

37. Shimizu K, Ashida H, Matsuura Y, Kanazawa K. Antioxidative bio-availability of artepillin $\mathrm{C}$ in Brazilian propolis. Arch Biochem Biophys 2004;424:181-8.

38. Konishi Y, Hitomi Y, Yoshida M, Yoshioka E. Absorption and bio-availability of artepillin $\mathrm{C}$ in rats after oral administration. J Agric Food Chem 2005;53:9928-33.

39. Villano D, Fernandez-Pachon MS, Moya ML, Troncoso AM, Garcia-Parrilla MC. Radical scavenging ability of polyphenolic compounds towards DPPH free radical. Talanta 2007;71:230-35.

40. Cai Y-Z, Sun M, Xing J, Luo Q, Corke H. Structure radical scavenging activity relationships of phenolic compounds from traditional Chinese medicinal plants. Life Sci 2006;78:2872-88.

41. Rice-Evans CA, Miller NJ, Paganga G. Structure-antioxidant activity relationships of flavonoids and phenolic acids. Free Radic Biol Med 1996;20:933-56.

42. Buratti S, Benedetti S, Cosio MS. Evaluation of the antioxidant power of honey, propolis and royal jelly by amperometric flow injection analysis. Talanta 2007;71:1387-92.

43. Pekkarinen SS, Stockmann H, Schwarz K, Heinonen IM, Hopia AI. Antioxidant activity and partitioning of phenolic acids in bulk and emulsified methyl linoleate. J Agric Food Chem 1999; 47:3036-43.

44. Koleva II, van Beek TA, Linssen JPH, de Groot A, Evstatieva LN Screening of plant extracts for antioxidant activity: a comparative study on the three testing methods. Phytochem Anal 2002;13:8-17.

45. Nagaoka T, Banskota AH, Tezuka Y, Harimaya Y, Koizumi K, Saiki I, et al. Inhibitory effects of caffeic acid phenethyl ester analogues on experimental lung metastasis of murine colon 26-L5 carcinoma cells. Biol Pharm Bull 2003;26:638-41.

46. Natella F, Nardini M, Felice MD, Scaccini C. Benzoic and cinnamic acid derivatives as antioxidants, structure-activity relation. J Agric Food Chem 1999;47:1453-9.

47. Shimazawa M, Chikamatsu S, Morimoto N, Mishima S, Nagai H, Hara $\mathrm{H}$. Neuroprotection by Brazilian green propolis in vitro and in vivo ischemic neuronal damage. Evid Based Complement Alternat Med 2005;2:201-7.

48. Wichi HP. Enhanced tumor development by butylated hydroxyanisole (BHA) from the perspective of effect on forestomach and oesophageal squamous epithelium. Food Chem Toxicol 1988:26:717-23.

49. Wang W, Weng X, Cheng D. Antioxidant activities of natural phenolic components from Dalbergia odorifera T. Chen. Food Chem 2000;71:45-9.

Received June 26, 2007; accepted November 27, 2007 


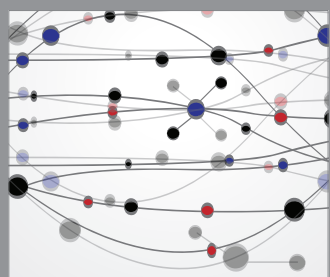

The Scientific World Journal
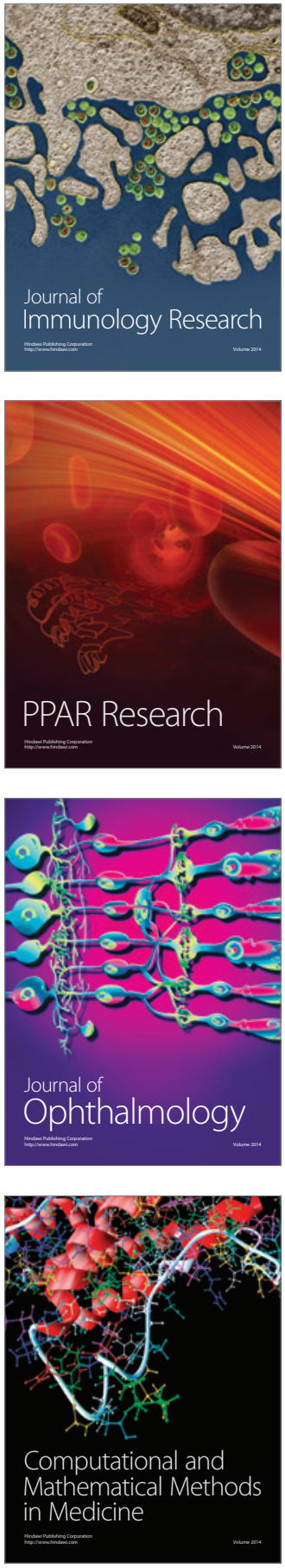

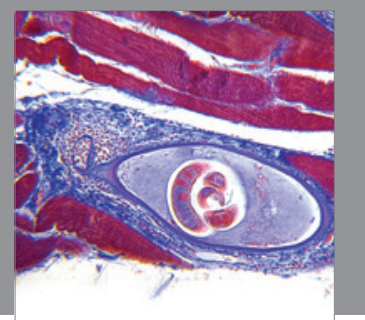

Gastroenterology

Research and Practice
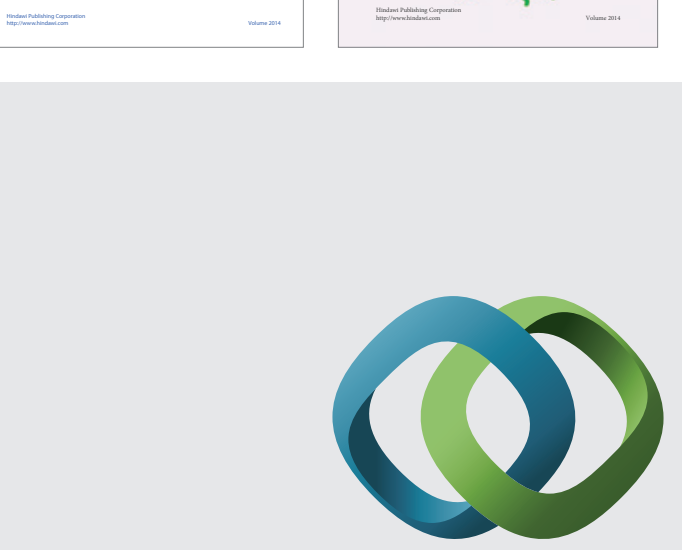

\section{Hindawi}

Submit your manuscripts at

http://www.hindawi.com
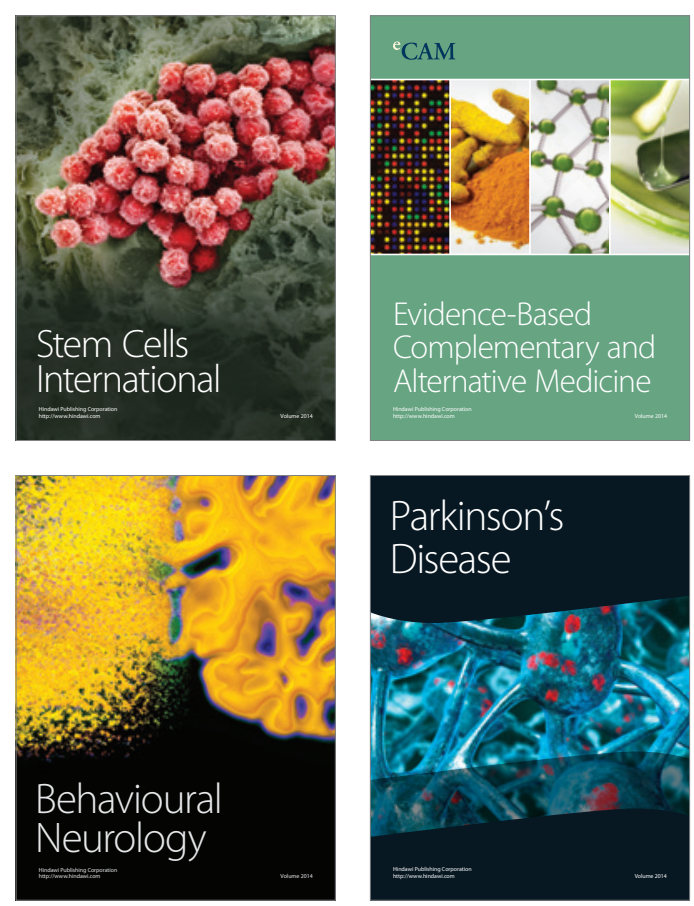

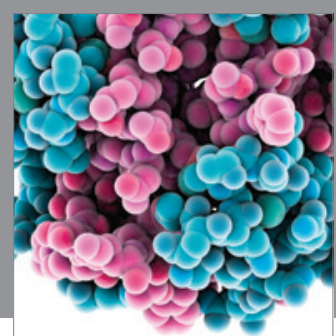

Journal of
Diabetes Research

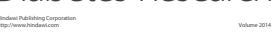

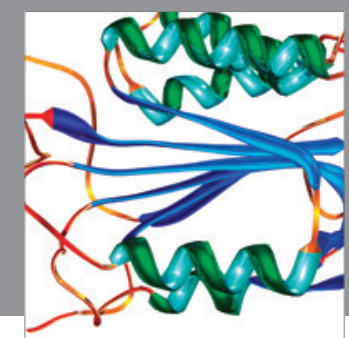

Disease Markers
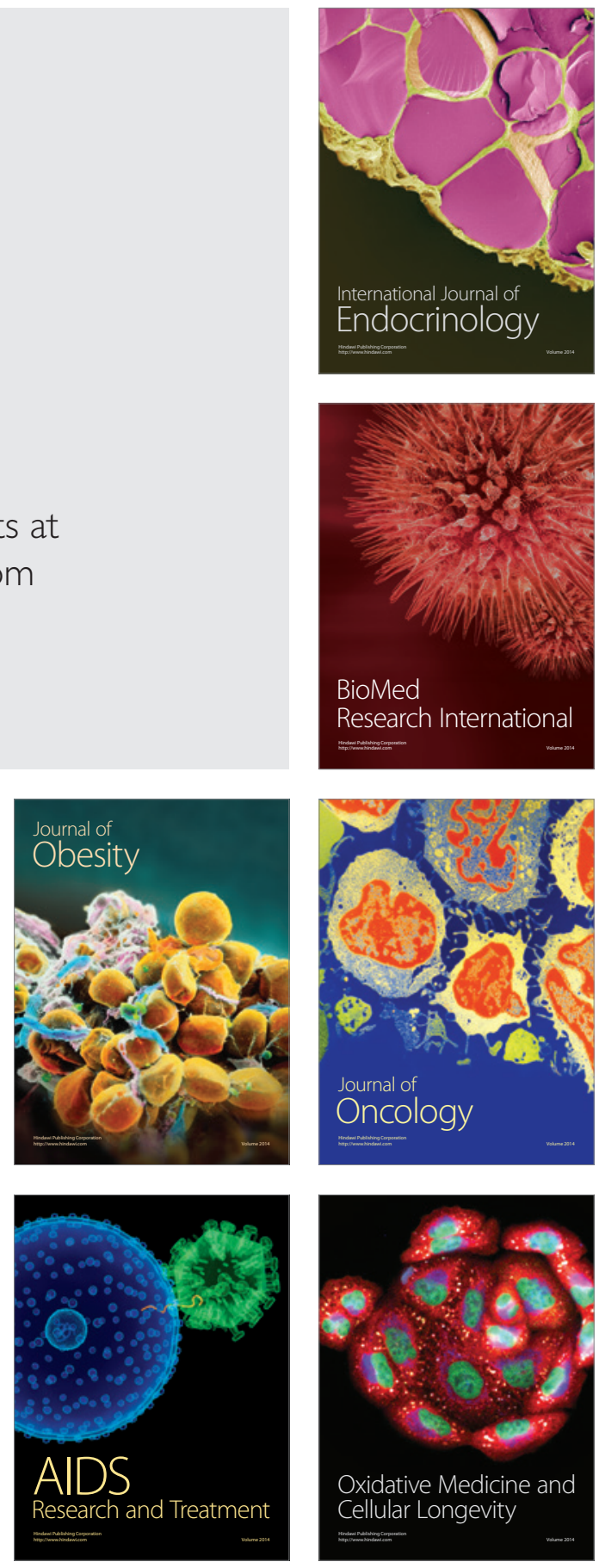